\title{
PENAPISAN MIKROALGA PENGHASIL KAROTENOID SERTA STUDI PENGARUH STRES NITROGEN DAN FOSFOR TERHADAP PRODUKSI $\beta$-KAROTEN PADA MIKROALGA Oocystis sp.
}

\section{Screening of Carotenoid Producing Microalgae and Study of the Effect of Nitrogen and Phosphorus Stress on the Production of $\beta$-Carotene in Microalgae Oocystis sp.}

\author{
Wahida Nia Elfiza ${ }^{1}$, Abdi Dharma ${ }^{2 \star}$ dan Nasril Nasir ${ }^{3}$ \\ ${ }_{1}$ Program Pascasarjana Kimia, Fakultas Matematika dan IImu Pengetahuan Alam, Universitas Andalas, Padang, \\ Sumatera Barat, Indonesia \\ ${ }^{2}$ Laboratorium Biokimia, Fakultas Matematika dan IImu Pengetahuan Alam, Universitas Andalas, Padang, \\ Sumatera Barat, Indonesia \\ ${ }^{3}$ Laboratorium Mikrobiologi, Fakultas Matematika dan IImu Pengetahuan Alam, Universitas Andalas, Padang, \\ Sumatera Barat, Indonesia \\ *Korespondensi Penulis: abdipogil@gmail.com
}

Diterima: 18 Maret 2019; Direvisi: 9 Mei 2019; Disetujui: 22 Juni 2019

\begin{abstract}
ABSTRAK
$\beta$-karoten merupakan karotenoid yang bermanfaat sebagai antioksidan. Penelitian ini bertujuan menapis mikroalga yang berpotensi mengandung karotenoid tinggi dan mempelajari pengaruh nitrogen dan fosfor terhadap produktivitas biomassa, kandungan pigmen fotosintesis dan $\beta$-karoten, pada mikroalga yang diisolasi dari perairan Danau Atas, Sumatra Barat. Penapisan mikroalga penghasil karotenoid dilakukan dengan memberikan paparan UV-A 326 $\mathrm{nm}$ terhadap kultur campuran mikroalga. Hasil penelitian menunjukkan bahwa 5 dari 18 spesies mampu bertahan pada proses penapisan. Pengaruh 9 jenis medium pertumbuhan dengan kriteria: tanpa $\mathrm{NaNO}_{3}, 3 \times \mathrm{NaNO}_{3}, 5 \times \mathrm{NaNO}_{3}, 10 x \mathrm{NaNO}_{3}$, Bold Basalt Medium (BBM) normal (kontrol), tanpa $\mathrm{KH}_{2} \mathrm{PO}_{4}, 3 \times \mathrm{KH}_{2} \mathrm{PO}_{4}, 5 \times \mathrm{KH}_{2} \mathrm{PO}_{4}$, dan10x $\mathrm{KH}_{2} \mathrm{PO}_{4}$ terhadap mikroalga terpilih (Oocystis sp.) diamati. Hasil menunjukkan kandungan $\beta$-karoten tertinggi ditemukan pada perlakuan $5 \mathrm{x} \mathrm{KH}_{2} \mathrm{PO}_{4}$ yaitu sebesar $0,22 \%$ dari berat kering mikroalga, dengan produktivitas biomassa $0,0015 \mathrm{~g} / \mathrm{mL} / \mathrm{hari}$, serta kandungan klorofil a, klorofil b dan karotenoid total yaitu $7,15 \mu \mathrm{g} / \mathrm{mL}, 0,81 \mu \mathrm{g} / \mathrm{mL}$ dan $6,67 \mu \mathrm{g} / \mathrm{mL}$. Berdasarkan penelitian ini dapat disimpulkan medium pertumbuhan dengan kandungan $5 \times \mathrm{KH}_{2} \mathrm{PO}_{4}$ merupakan medium yang cocok bagi pertumbuhan Oocystis sp. untuk mendapatkan biomassa dengan kandungan $\beta$-karoten dan karotenoid tinggi tanpa harus menurunkan produktivitas biomassanya.
\end{abstract}

KATA KUNCI : mikroalga, $\beta$-karoten, Oocystis sp., stres nitrogen, stres fosfor

\section{ABSTRACT}

$\beta$-carotene is a carotenoid that is useful as an antioxidant. Present study aims to screening high microalgae which contain carotenoids from water of Danau Atas lake (West Sumatra Province), and study the effect of nitrogen and phosphorus on biomass productivity, photosynthetic and $\beta$-carotene pigment content. Screening of carotenoid-producing microalgae was carried out by exposing UV-A $326 \mathrm{~nm}$ to mixed microalgae cultures. The results showed that 5 of the 18 species were able to survive in the screening process. The effect of growth medium, i.e. without $\mathrm{NaNO}_{3}, 3 x \mathrm{NaNO}_{3}, 5 x \mathrm{NaNO}_{3}, 10 x$ $\mathrm{NaNO}_{3}$, normal Bold Basalt Medium (BBM) (control), without $\mathrm{KH}_{2} \mathrm{PO}_{4}, 3 x \mathrm{KH}_{2} \mathrm{PO}_{4}, 5 x \mathrm{KH}_{2} \mathrm{PO}_{4}$, and $10 \mathrm{x}$ $\mathrm{KH}_{2} \mathrm{PO}_{4}$ on of selected microalgae (Oocystis sp.) was carried out. The result showed that the highest content of $\beta$-carotene of Oocystis sp. was obtained with $5 x \mathrm{KH}_{2} \mathrm{PO}_{4}$ which was $0.22 \%$ of the dry weight of biomass. Biomass productivity was $0.0015 \mathrm{~g} / \mathrm{mL} /$ day and the chlorophyll a, chlorophyll $b$ and total carotenoids contents were $7.15 \mu \mathrm{g} / \mathrm{mL}, 0.81 \mu \mathrm{g} / \mathrm{mL}$ and $6.67 \mu \mathrm{g} / \mathrm{mL}$, respectively. Based on this research, $5 x \mathrm{KH}_{2} \mathrm{PO}_{4}$ can be concluded as a suitable medium for Oocystis sp. to obtained high $\beta$ carotene and carotenoid of Oocystis sp. without reducing biomass productivity.

KEYWORDS: microalgae, $\beta$-carotene, Oocystis sp., nitrogen stress, phosphorus stress 


\section{PENDAHULUAN}

Karotenoid adalah pigmen alami yang ditemukan pada bakteri, alga, fungi dan tumbuhan tetapi tidak diproduksi oleh hewan. Karotenoid banyak dimanfaatkan dalam berbagai bidang industri seperti produk makanan kesehatan, kosmetik, suplemen vitamin, dan zat adiktif. Beberapa jenis karotenoid yang dipelajari secara luas adalah $\beta$-karoten, likopen, lutein, zeaxantin dan astaxantin (Coates, Trentacoste, \& Gerwick, 2013).

$\beta$-karoten merupakan provitamin A yang bisa dikonversi menjadi retinol. Vitamin A berfungsi menurunkan resiko gangguan pada mata (macular degeneration). Selain itu $\beta$-karoten juga berfungsi sebagai inhibitor dalam pertumbuhan sel kanker dengan cara menginduksi terjadinya apoptosis (Coates et al., 2013).

$\beta$-karoten sebagai metabolit sekunder pada mikroalga dapat disintesis oleh sel karena adanya stres oksidatif dari lingkungan. Salah satu bentuk stres oksidatif adalah berupa cahaya kuat (Asker \& Ohta, 1999; Stafsnes et al., 2010). Cahaya kuat yang berasal dari intensitas cahaya matahari di musim panas mengandung sinar ultraviolet (UV) pada panjang gelombang tertentu. Paparan radiasi UV-A (320-400 $\mathrm{nm})$ dan UV-B (280-320 $\mathrm{nm}$ ) berbahaya bagi sel, radiasi UV-A menghasilkan radikal bebas yang membahayakan DNA sedangkan paparan UV-B menyasar DNA dan protein. Sebagai antioksidan, $\beta$ karoten yang merupakan bagian dari karotenoid mampu melindungi sel dari radikal bebas (Stafsnes et al., 2010). Paparan sinar UV akan meningkatkan produksi spesies oksigen reaktif (reactive oxigen species/ROS) oleh sel, yang harus segera dinetralkan oleh sistem antioksidan sel. Spesies yang tidak mempunyai sistim antioksidan yang baik tidak mampu bertahan hidup, sedangkan spesies yang mempunyai sistem antioksidan yang baik akan bertahan.

Stres oksidatif dapat menyebabkan akumulasi $\beta$ karoten karena perubahan jalur metabolit sekunder $\beta$ karoten pada mikroalga. Biosintesis $\beta$-karoten dapat terjadi karena adanya stres abiotik. Salah satu stres abiotik yaitu dengan pembatasan nutrien. Pembatasan nutrien mengacu kepada stres kandungan nutrien pada medium kultivasi mikroalga seperti stres nitrogen dan fosfor (Paliwal et al., 2017). Studi memperlihatkan adanya peningkatan ekspresi gen likopen b-cyclase (Lcy-b) dari mikroalga Dunaliella salina karena kondisi stres lingkungan berupa paparan stres abiotik salinitas dan cahaya tinggi yang dikombinasi dengan pembatasan nutrien. Kombinasi dengan faktor pembatasan nutrien meningkatkan level steady-state
mRNA b-cyclase (Lcy-b) D. salinadibandingkan dengan hanya melibatkan dua faktor stres abiotik salinitas dan cahaya tinggi. Hasil penelitian lain menunjukkan bahwa pembatasan (kekurangan) nutrien merupakan faktor penting untuk akumulasi $\beta$-karoten pada mikroalga (Ramos et al., 2008).

Tujuan dari penelitian ini adalah menapis mikroalga yang mengandung karotenoid tinggi dan mempelajari pengaruh stres nitrogen dan fosfor terhadap produktivitas biomassa, pigmen fototosintesis dan $\beta$ karoten pada mikroalga hasil penapisan.

\section{BAHAN DAN METODE}

\section{Bahan}

Sampel mikroalga diisolasi dari perairan Danau Atas (Kabupaten Solok, Provinsi Sumatera Barat) dengan titik koordinat $1^{\circ} 03^{\prime} 54.1^{\prime \prime S} 100^{\circ} 44^{\prime} 51.5 " \mathrm{E}$. Sampel diambil dengan plankton net ukuran pori 30 micron pada kedalaman \pm 1 meter, \pm 3 meter dan \pm 5 meter. Sampel dimasukkan ke dalam botol kaca streril dan diberi label. Sebagian sampel diberi formalin $4 \%$ untuk pengamatan bentuk morfologi mikroalga dengan mikroskop jenis binokuler dan bagian kedua, dikultivasi dengan medium pertumbuhan Medium Bold Basalt (BBM).

Bahan-bahan lain yang digunakan dalam penelitian ini adalah bahan-bahan yang diperlukan dalam pembuatan medium BBM, dan Growmore (GM). Di samping itu juga dibutuhkan standar $\beta$-karoten (Sigma Aldrich) untuk pengujian.

\section{Metode}

\section{Penapisan dan isolasi}

Sebanyak $1 \mathrm{~mL}$ kultur sampel dalam medium BBM diteteskan ke dalam petridish steril, lalu ditambahkan $10 \mathrm{~mL}$ medium BBM steril. Sampel tersebut disinari dengan lampu UV-A (326 nm) selama 3 jam dan diinkubasi pada suhu ruang hingga sampel menghijau pudar (20 hari). Setelah itu, diamati dengan binokuler (Olympus BX51). Mikroalga yang teramati hidup merupakan mikroalga yang mampu bertahan pada proses penapisan. Mikroalga yang bertahan selanjutnya diisolasi.

Isolasi dilakukan dengan cara meneteskan cuplikan sampel menggunakan mikropipet di atas kaca preparat dan ditutup dengan kaca objek, kemudian diamati dengan mikroskop. Jika yang diamati terbawa satu sel, maka kaca peparat dan kaca objek dicuci menggunakan medium BBM steril, cuciannya ditampung ke dalam botol vial (botol kultur 
yang telah berisi medium BBM steril), lalu dibiarkan selama sebulan hingga menghijau homogen. Mikroalga yang telah terisolasi dijaga kemurniannya sampai menghijau pudar, setelah itu dipindahkan ke dalam botol kaca $500 \mathrm{~mL}$ untuk memperbanyak biomassanya.

\section{Pembuatan medium pertumbuhan mikroalga}

Medium kultivasi yang digunakan adalah GM dan BBM. Medium GM memiliki persentase komposisi nitrogen $(N)$, fosfor $(P)$ dan kalium $(K)$ bervariasi yaitu GM 6-30-30, 10-55-10, 20-20-20 dan 32-10-10, sedangkan komposisi zat lainnya memiliki persentase yang sama yaitu kalsium $(\mathrm{Ca}) 0,05 \%$, Magnesium (Mg) 0,10\%, Sulfur (S) 0,20\%, Boron (B) 0,02\%, Tembaga (Cu) $0,05 \%$, Iron (Fe) 0,10\%, Mangan (Mn) $0,05 \%$, Molibdenum (Mo) 0,0005\% dan Zink (Zn) $0,05 \%$. Medium kultivasi GM dibuat dengan cara melarutkan $0,2 \mathrm{~g}$ serbuk $\mathrm{GM}$ ke dalam $1 \mathrm{~L}$ aquades. Medium GM dipilih sebagai medium seleksi karena lebih praktis dan hemat dibandingkan medium BBM. Medium BBM terdiri dari makronutrien $\mathrm{NaNO}_{3} 25 \mathrm{~g} / \mathrm{L}$, $\mathrm{MgSO}_{4} .7 \mathrm{H}_{2} \mathrm{O} 7,5 \mathrm{~g} / \mathrm{L}, \mathrm{NaCl} 2,5 \mathrm{~g} / \mathrm{L}, \mathrm{K}_{2} \mathrm{HPO}_{4} 7,5 \mathrm{~g} / \mathrm{L}$, $\mathrm{KH}_{2} \mathrm{PO}_{4} 17,5 \mathrm{~g} / \mathrm{L}, \mathrm{CaCl}_{2} \cdot 2 \mathrm{H}_{2} \mathrm{O} 2,5 \mathrm{~g} / \mathrm{L}$, dan mikronutrien yaitu trace element $\left(\mathrm{ZnSO}_{4} \cdot 7 \mathrm{H}_{2} \mathrm{O} 8,82 \mathrm{~g} / \mathrm{L}, \mathrm{MnCl}_{2} \cdot 4 \mathrm{H}_{2} \mathrm{O}\right.$ $1,44 \mathrm{~g} / \mathrm{L}, \mathrm{CuSO}_{4} \cdot 5 \mathrm{H}_{2} \mathrm{O} 1,57 \mathrm{~g} / \mathrm{L}, \mathrm{Co}\left(\mathrm{NO}_{3}\right)_{2} \cdot 6 \mathrm{H}_{2} \mathrm{O} 0,49$ $\mathrm{g} / \mathrm{L}$ ), EDTA-KOH solution (EDTA 50 , dan $\mathrm{KOH} 31 \mathrm{~g}$ ), ferric solution $\left(\mathrm{FeSO}_{4} \cdot 7 \mathrm{H}_{2} \mathrm{O} 4,98 \mathrm{~g} / \mathrm{L}\right.$, dan $\mathrm{H}_{2} \mathrm{SO}_{4}$ conc. 10 tetes), dan $\mathrm{H}_{3} \mathrm{BO}_{3} 11,42 \mathrm{~g} / \mathrm{L}$. Medium BBM dibuat dengan cara melarutkan $10 \mathrm{~mL}$ masing-masing makronutrien dan $1 \mathrm{~mL}$ mikronutrien dalam $1 \mathrm{~L}$ aquades, lalu distrerilisasi dengan autoclave dan didinginkan sebelum digunakan (Singh, Gupta, Guldhe, Rawat, \& Bux, 2015)

\section{Seleksi medium}

Isolat mikroalga dikultur dengan 5 jenis medium, yaitu BBM, GM6-30-30, GM10-55-10, GM 20-20-20 dan GM32-10-10, dan pertumbuhannya dipantau berdasarkan nilai optical density OD-400nm dari kultur dengan spektrofotometer UV-Vis (Thermo Scientific Genesys). Medium dengan pertumbuhan mikroalga terbaik digunakan sebagai medium pertumbuhan untuk penelitian selanjutnya. Mikroalga dipanen pada fasa stationer dengan cara sentrifugasi pada kecepatan $1914 \mathrm{~g}$. Biomassa mikroalga yang didapat dikeringkan pada kondisi gelap selama 3 hari, kemudian disimpan pada suhu $4{ }^{\circ} \mathrm{C}$ sampai waktu analisis (Kee et al., 2017).

Tahap induksi dengan stres nitrogen dan fosfor

Penerapan stres nutrien yang berupa kekurangan atau kelebihan kadar $\mathrm{N}$ dan $\mathrm{P}$ pada medium BBM dilakukan setelah kultur mikroalga di dalam medium BBM mencapai akhir fasa eksponensial (hari ke 18).
Kultur berumur 18 hari disentrifugasi pada kecepatan $1914 \mathrm{~g}$, kemudian biomasa mikroalga yang diperoleh dimasukkan ke dalam medium BBM termodifikasi berikut: BBM kekurangan $\mathrm{N}$ dan $\mathrm{P}$ mengandung $0 \mathrm{M}$ $\mathrm{NaNO}_{3}, 0 \mathrm{M} \mathrm{K \textrm {K } _ { 2 }} \mathrm{PO}_{4}$; $\mathrm{BBM}$ kelebihan $\mathrm{N}$ mengandung $1 \mathrm{M} \mathrm{NaNO}_{3}$ (3 kali lipat), 1,5 $\mathrm{M} \mathrm{NaNO}_{3}$ (5 kali lipat) dan $3 \mathrm{M} \mathrm{NaNO}_{3}$ (10 kali lipat); BBM kelebihan $\mathrm{P}$ mengandung $0,4 \mathrm{M} \mathrm{KH}_{2} \mathrm{PO}_{4}$ (3 kali lipat), 0,6 $\mathrm{M} \mathrm{KH}_{2} \mathrm{PO}_{4}$ (5 kali lipat), 1,3 $\mathrm{M} \mathrm{KH}_{2} \mathrm{PO}_{4}$ (10 kali lipat). Medium kontrol adalah BBM dalam kondisi normal dengan 0,3 $\mathrm{M} \mathrm{NaNO}_{3}$ dan $0,1 \mathrm{M} \mathrm{KH}_{2} \mathrm{PO}_{4}$, lalu dikultur selama 3 hari (Moussa, Chtourou, Karray, Sayadi, \& Dhouib, 2017).

\section{Penentuan pertumbuhan dan produktivitas biomassa}

Pertumbuhan mikroalga diamati setiap hari dengan pengukuran $\mathrm{OD}_{400 \mathrm{~nm}}$ dan biomasa sel kering (DCW) $\mathrm{mg} / \mathrm{L}$. Produktifitas biomassa (BP) ditentukan nilainya dengan mengacu kepada persamaan BP (mg/L/hari) (Moussa et al., 2017)

\section{Penentuan pigmen fotosintesis}

Kandungan pigmen klorofil a, klorofil b dan karotenoid total ditentukan berdasarkan metoda Lichtenthaler (1987). Kultur mikroalga (2 mL) disentrifugasi pada kecepatan $1914 \mathrm{~g}$ selama 5 menit, pelet diambil lalu ditambahkan metanol lalu diinkubasi pada suhu $60{ }^{\circ} \mathrm{C}$ selama 30 menit, kemudian didinginkan pada suhu ruang dan disentrifugasi ulang pada kecepatan $1914 \mathrm{~g}$ selama 5 menit. Pigmen terlarut diukur pada panjang gelombang 470, 650 dan $665 \mathrm{~nm}$.

Kandungan pigmen ditentukan dengan formulasi sebagai berikut :

$\begin{aligned} & \text { Klorofil } a(\mu \mathrm{g} / \mathrm{mL})=\left(16,72 \times \mathrm{A}_{665}\right)-\left(9,16 \times \mathrm{A}_{652}\right) \\ & \text { Klorofil b }(\mu \mathrm{g} / \mathrm{mL})=\left(34,09 \times \mathrm{A}_{652}\right)-\left(15,28 \times \mathrm{A}_{665}\right) \\ & \text { Karotenoid }(\mu \mathrm{g} / \mathrm{mL})=(1000 \times \mathrm{A} 470)-(1,63 \times \text { klorofil } \\ & \text { a) }-(104,96 \times \text { klorofil b) } / 221\end{aligned}$

\section{Analisis b-karoten dengan HPLC}

Standar $\beta$-karoten (Sigma Aldrich) ditimbang sebanyak $5 \mathrm{mg}$, lalu dilarutkan dalam $10 \mathrm{~mL}$ pelarut (fasa gerak) diklorometan : asetonitril : metanol dengan perbandingan 20:70:10 (v/v/v), untuk mendapatkan larutan stok $\beta$-karoten $500 \mathrm{ppm}$. Larutan standar $\beta$-karoten 37,5 ppm, 75 ppm, 150 ppm, dan $300 \mathrm{ppm}$ dibuat dengan cara mengencerkan larutan stok $\beta$-karoten.

Sebelum pengukuran dengan HPLC, pigmen diekstrak dengan cara maserasi sebanyak $0,1 \mathrm{~g}$ 
biomassa kering mikroalga dengan $5 \mathrm{~mL}$ aseton selama 24 jam sebanyak 3 kali, hingga ekstrak tidak berwarna. Selanjutnya ekstrak disentrifugasi pada kecepatan $4000 \mathrm{~g}$ selama 3 menit untuk memisahkan sisa-sisa biomassanya, lalu dikeringkan dalam kondisi gelap selama 1 malam. Ekstrak kering dilarutkan dalam $2 \mathrm{~mL}$ pelarut (fasa gerak) diklorometan : asetonitril : metanol dengan perbandingan 20:70:10. Selanjutnya $\beta$-karoten standar dan sampel diinjeksikan ke instrumen HPLC (Shimadzu SPD $20 \mathrm{~A}$ / SPD-20AV) yang dilengkapi dengan kolom C18 (Shim-pack VP-ODS LUNA). Absorbansi diukur pada panjang gelombang $450 \mathrm{~nm}$ dengan kecepatan alir bahan $0,9 \mathrm{~mL} /$ menit, pada temperatur $25^{\circ} \mathrm{C}$ (Sekatresna, Dharma, Zein, \& Chaidir, 2016). Kadar $\beta$-karoten pada mikroalga terpilih dihitung dengan menggunakan persamaan regresi yang dihasilkan dari analisis HPLC $\beta$-karoten standar. Persentase $\beta$-karoten dihitung dengan persamaan berikut :

$$
\beta \text {-karoten }(\%)=\frac{\begin{array}{c}
\text { Berat } \beta \text {-karoten dalam } \\
\text { sampel }(\mathrm{mg})
\end{array}}{\begin{array}{c}
\text { Berat biomassa kering } \\
\text { mikroalga }(\mathrm{mg})
\end{array}} \times 100 \%
$$

\section{Analisis statistik}

Analisis statistik dilakukan dengan perangkat lunak SPSS dengan metoda One Way Analysis Of Variance (ANOVA). Perlakuan dilakukan triplo. Signifikan hasil uji dipertimbangkan ketika $p<0,05$.

\section{HASIL DAN PEMBAHASAN}

\section{Keragaman Spesies Mikroalga}

Sampel diambil dari air Danau Atas yang terletak pada ketinggian di atas 1400 mdpl dengan suhu relatif rendah yaitu berkisar $18,5^{\circ} \mathrm{C}$. Mikroorganisme yang berasal dari lingkungan ekstrim mampu memproduksi karotenoid dengan jumlah tinggi salah satunya lingkungan dengan suhu rendah (Strand, Shivaji, \& Liaaen-Jensen, 1997), sehingga dari lokasi sampel diharapkan mikroalga yang terisolasi berpotensi sebagai sumber karotenoid seperti $\beta$-karoten.

Dari sampel air Danau Atas, dapat dikenali sebanyak 18 spesies mikroalga berdasarkan morfologinya. Jenisjenis tersebut diamati dengan mikroskop binokuler dan diidentifikasi berdasarkan sumber www. algabase.org. Morfologi mikroalga yang teridentifikasi dari Danau Diatas disajikan pada Gambar 1.
Penapisan dengan cara penyinaran UV-A $326 \mathrm{~nm}$ pada kultur campuran 18 spesies mikroalga menyisakan 5 jenis mikroalga yaitu Oocystis sp. Denticula tenuis, Gleocystis schroeteri, Scenedesmus longispina dan Fragillaria construens. Mikroalga yang masih bertahan merupakan mikroalga yang berpotensi mengandung karotenoid tinggi. Namun, hanya Oocystis sp. yang dipelajari lebih lanjut pada penelitian ini.

\section{Medium Pertumbuhan Mikroalga}

Kecocokan terhadap medium pertumbuhan dapat dilihat melalui kurva waktu terhadap nilai $\mathrm{OD}_{400 \mathrm{~nm}}$ (Gambar 2). Terlihat pertumbuhan Oocystis sp. terbaik adalah pada medium BBM, diikuti oleh medium GM 32-10-10. Masing-masing spesies mikroalga mempunyai kesesuaian komposisi medium yang berbeda. Pertumbuhan Scenedesmus rubescens di dalam medium GM 32-10-10 terlihat lebih baik dibandingkan di dalam medium BBM, sementara Galdieria sulphuraria tumbuh dengan pola dan tingkat pertumbuhan yang sama di dalam medium BBM maupun di dalam GM 32-10-10 (Hernandi, Dharma, \& Armaini, 2018). Kedua mikroalga terakhir berasal dari sumber air yang sama dengan Oocystis sp.

Pertumbuhan Oocystis sp. sama sekali tidak didukung oleh medium GM 6-30-30, dan GM 10-5510, sedangkan GM 32-10-10 dapat mendukung pertumbuhan Oocystis sp, namun masih lebih rendah dibandingkan dengan medium BBM. Diduga kandungan N pada medium GM 6-30-30 dan GM 1055-10 sangat kecil sehingga tidak bisa mendukung pertumbuhan mikroalga Oocystis sp. (Gambar 2). Berdasarkan hal tersebut, persentase optimum $\mathrm{N}$ untuk mendukung pertumbuhan Oocystis sp. adalah $34 \%$ seperti yang terkandung di dalam medium BBM.

Nutrien adalah faktor penting dalam produksi biomassa mikroalga, terlebih pada unsur makronutrien seperti N, P dan K. Medium GM 32-10-10 yang memiliki kandungan $\mathrm{N}$ lebih tinggi dari $\mathrm{P}$ dan $\mathrm{K}$-nya, terdeteksi memiliki umur/masa kultur Oocystis sp. yang lebih panjang serta biomassa lebih tinggi dibandingkan dengan medium GM lainnya. Namun pertumbuhan Oocystis sp. lebih baik pada medium BBM daripada medium GM 32-10-10. Dalam medium BBM terkandung $\mathrm{N}$ sebesar $25 \mathrm{~g} / \mathrm{L}$ dari $\mathrm{NaNO}_{3}, \mathrm{P}$ sebesar $17,5 \mathrm{~g} / \mathrm{L}$ dari $\mathrm{KH}_{2} \mathrm{PO}_{4}$ dan $\mathrm{K}$ sebesar $7,5 \mathrm{~g} / \mathrm{L}$ dari $\mathrm{K}_{2} \mathrm{HPO}_{4}$. Pada komposisi demikian, didapatkan rata-rata produktifitas bioamassa mikroalga Oocystis $\mathrm{sp}$. sekitar 0,7 g/L. Dari lima medium yang telah diujicobakan medium BBM memberikan hasil pada 


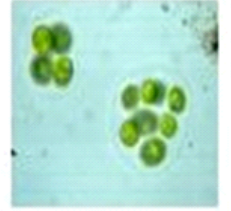

a

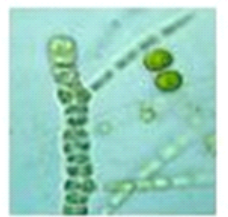

9

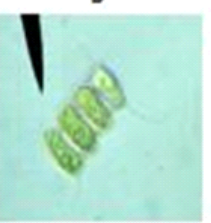

m

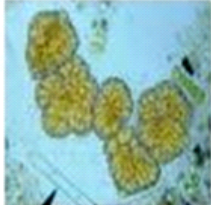

b

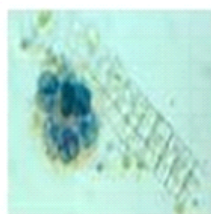

h

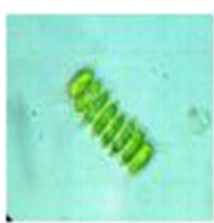

n

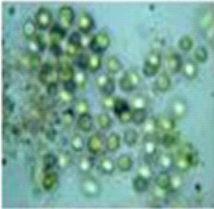

c

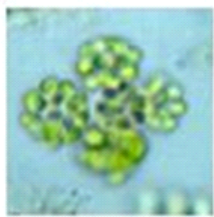

i

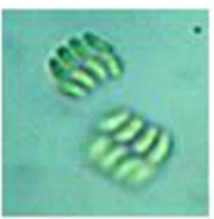

0

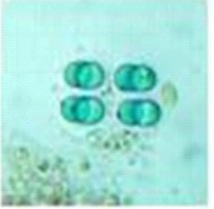

d

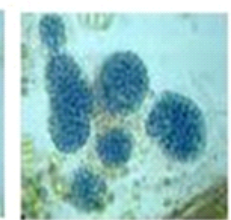

j

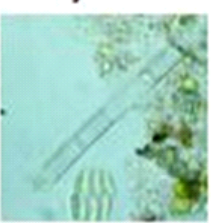

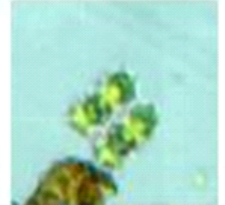

e

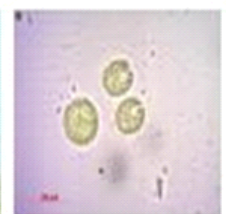

k

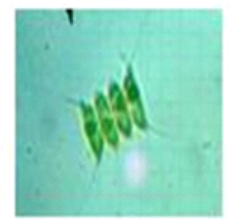

q

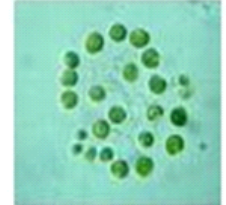

f

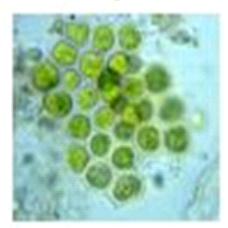

I

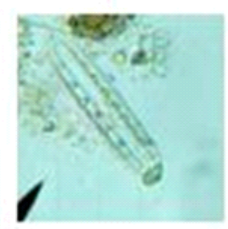

r

Gambar 1. Mikroalga yang teridentifikasi dari perairan Danau Atas, Alahan Panjang, Kabupaten Solok dengan perbesaran 400x (a) Asterococcus limneticus, (b) Botryococcus braunii, (c) Chroococcus dispersus, (d) C. limnticus, (e) Coeleastrum morus, (f) Dyctiosphaerium pulchellum, (g) Fischerella mucicola, (h) Fragillaria construens, (i) Gleocystis schroeteri, (j) Microcystis aeruginosa, (k) Oocystis sp, (l) Pediastrum integrum, (m) Scenedesmus quadricauda, (n) S. obliquus, (o) S. arcuatus, (p) Aulacoseira italica, (q) S. Iongispina, (r) Denticula tenuis

Figure 1. Microalgae identified from the waters of Danau Atas, Alahan Panjang, Kabupaten Solok with a magnification of $400 \times$ (a) Asterococcus limneticus, (b)Botryococcus braunii, (c) Chroococcus

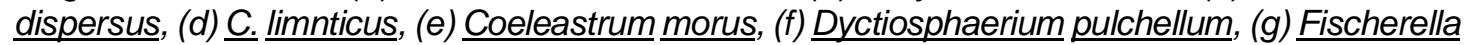
mucicola, (h) Fragillaria construens, (i) Gleocystis schroeteri, (j) Microcystis aeruginosa, (k)

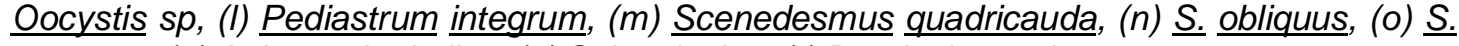
arcuatus, $(p)$ Aulacoseira italica, $(q) \underline{\text { S. }}$ longispina, $(r)$ Denticula tenuis

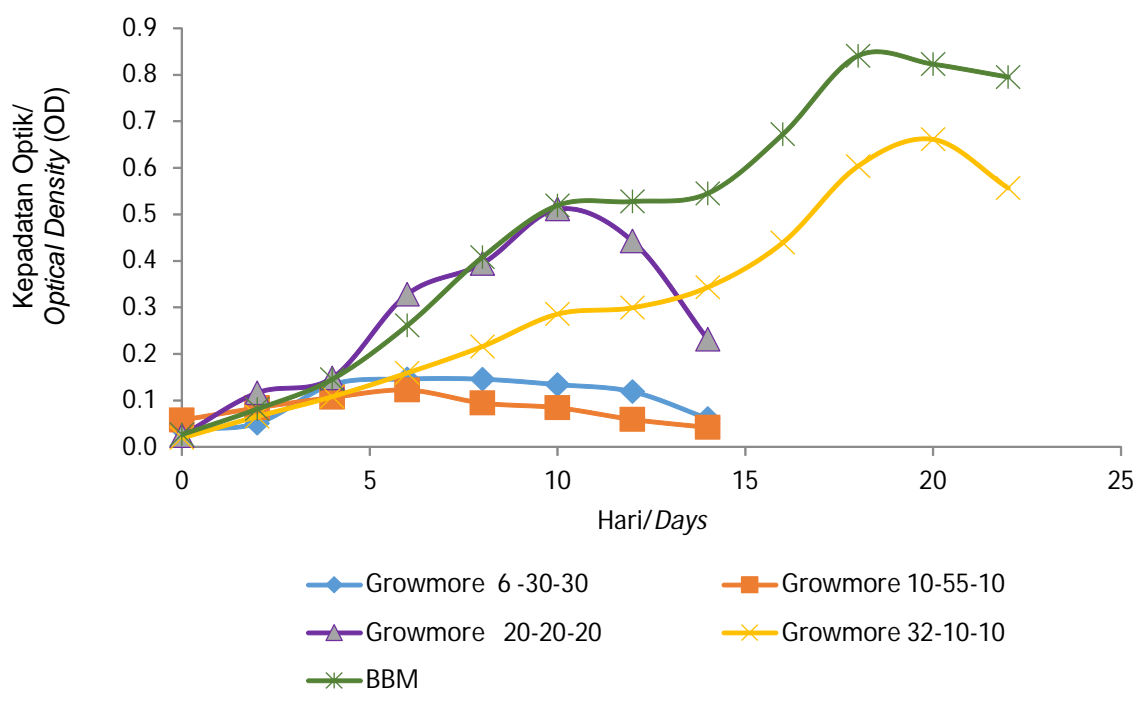

Gambar 2. Pertumbuhan mikroalga Oocystis sp. pada media BBM dan Growmore Figure 2. Oocystis sp. growth on BBM and Growmore media 
kultur Oocystis sp. terbaik, sehingga digunakan pada kultur selanjutnya.

\section{Efek induksi terhadap produktivitas biomassa Oocystissp.}

Produktivitas biomassa mikroalga Oocystis sp. tertinggi diperoleh pada perlakuan induksi dalam kondisi kosentrasi $5 \times \mathrm{NaNO}_{3}$ yaitu sekitar $0,0017 \mathrm{~g} /$ $\mathrm{mL} /$ hari (Gambar 3). Hal ini menunjukkan keadaan medium induksi Oocystis sp. pada konsentrasi optimal, sedangkan induksi dengan kelebihan $\mathrm{NaNO}_{3}$ lainnya dan medium BBM normal (kontrol) memiliki produktivitas yang lebih rendah (Gambar 3). Stres nitrogen $(\mathrm{N})$ berpengaruh terhadap produktivitas biomassa Oocystis sp. $(p<0,05)$. Perlakuan konsentrasi $\mathrm{N}$ yang kurang dan berlebih dari kondisi normal dapat memberikan efek berbeda terhadap produktivitas biomassa Oocystis sp. Nitrogen adalah faktor penting pada medium pertumbuhan dengan konsentrasi tertentu. Kelebihan atau kekurangan akan mengganggu pertumbuhan sel. Hal ini tergantung dari kondisi kultur dan jenis spesies (Li, Horsman, Wang, Wu, \& Lan, 2008).
Keberadaan $\mathrm{N}$ dalam medium pertumbuhan sangat berpengaruh terhadap produktivitas biomassa. Produktivitas biomassa Oocystis sp.dalam kondisi medium tanpa $\mathrm{N}\left(0 \mathrm{M} \mathrm{NaNO}_{3}\right)$ terdeteksi paling rendah yaitu sekitar $0,0011 \mathrm{~g} / \mathrm{mL} /$ hari. Barsanti dan Gualtieri (2006) dalam Wehr (2018) menyatakan bahwa, N merupakan komponen utama untuk pertumbuhan alga karena fungsinya dalam komposisi stuktural sel dan fungsi protein seperti enzim dalam sel alga. Namun hasil penelitian menunjukkan mikroalga masih dapat bertahan hidup walaupun tanpa N. Hal ini karena mikroalga mampu memanfaatkan cadangan $\mathrm{N}$ seperti klorofil yang dikonversi ke protein, asam nukleat dan isi sel lainnya. Li et al. (2008) menyatakan hal tersebut dilakukan untuk menopang pertumbuhan mikroalga sehingga mikroalga masih bisa bertahan.

Selain $N$, unsur $P$ juga berpengaruh terhadap pertumbuhan dan produktivitas biomassa Oocystis sp. Kultur mikroalga Oocystis sp. pada medium $0 \mathrm{M}$ $\mathrm{KH}_{2} \mathrm{PO}_{4}$ (defisiensi fosfor) memiliki produktifitas biomassa yang rendah. Hal tersebut senada dengan hasil penelitian yang didapatkan oleh KozlowskaSzerenos et al. (2000) terhadap C. vulgaris. Pada

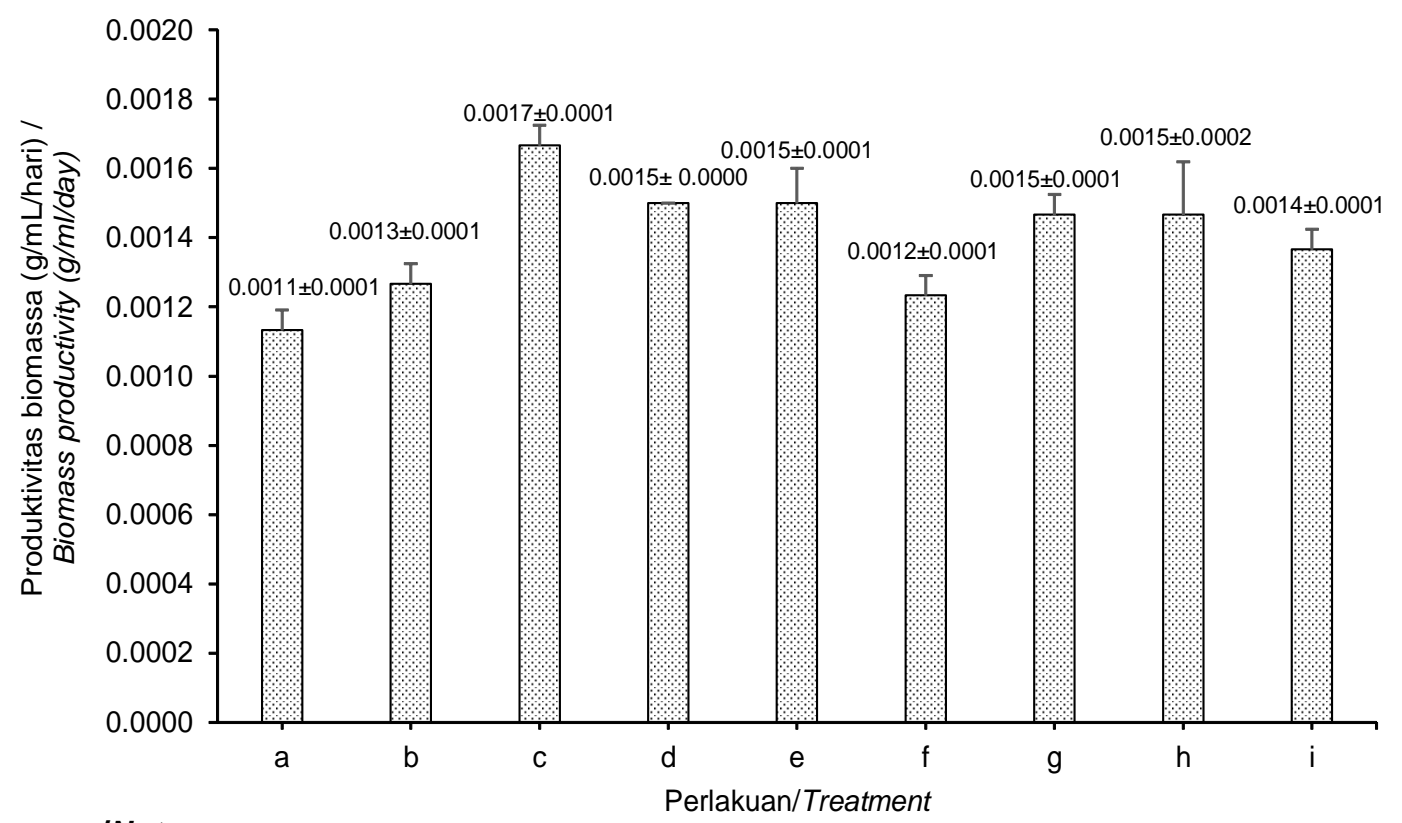

\section{Keterangan/Notes:}

$\mathrm{a}=\mathrm{BBM}$ tanpa $\mathrm{NaNO}_{3} / \mathrm{BBM}$ without $\mathrm{NaNO}_{3}$ $\mathrm{b}=\mathrm{BBM}$ dengan $3 \times \mathrm{NaNO}_{3} / \mathrm{BBM}$ with $3 \times \mathrm{NaNO}_{3}$ $\mathrm{C}=\mathrm{BBM}$ dengan $5 \times \mathrm{NaNO}_{3} / \mathrm{BBM}$ with $5 \times \mathrm{NaNO}_{3}$

$\mathrm{d}=\mathrm{BBM}$ dengan 10x $\mathrm{NaNO}_{3} / \mathrm{BBM}$ with $10 \times \mathrm{NaNO}_{3}$ $\mathrm{e}=\mathrm{BBM}$ Normal/Normal BBM
$\mathrm{f}=\mathrm{BBM}$ tanpa $\mathrm{KH}_{2} \mathrm{PO}_{4} / \mathrm{BBM}$ without $\mathrm{KH}_{2} \mathrm{PO}_{4}$ $\mathrm{g}=\mathrm{BBM}$ dengan $3 \times \mathrm{KH}_{2} \mathrm{PO}_{4} / B B M$ with $3 \times \mathrm{KH}_{2} \mathrm{PO}_{4}$ $\mathrm{h}=\mathrm{BBM}$ dengan $5 \times \mathrm{KH}_{2} \mathrm{PO}_{4} / \mathrm{BBM}$ with $5 \times \mathrm{KH}_{2} \mathrm{PO}_{4}$ $\mathrm{i}=$ BBM dengan $10 \times \mathrm{KH}_{2}^{2} \mathrm{PO}_{4} / B B M$ with $10 \times \mathrm{K}_{2} \mathrm{PO}_{4}$

Gambar 3. Produkvitas biomassa mikroalga Oocystis $s p(\mathrm{~g} / \mathrm{mL} /$ hari) selama proses kultivasi 21 hari Figure 3 . Microalgae Oocystis sp ( $\mathrm{g} / \mathrm{mL} /$ day) biomass productivity during 21 days cultivation process. 
penelitian mereka terjadi penurunan pertumbuhan Chorella vulgaris dari $30 \%$ hingga $40 \%$ akibat pembatasan jumlah fosfor pada kultur dibandingkan dengan mikroalga yang dikultur dalam medium kontrol. Walaupun demikian, beberapa mikroalga masih dapat tumbuh jika terjadi defisiensi sumber fosfor karena proses asimilasi fosfat (Li et al., 2008).

Hasil penelitian ini juga menunjukkan pengaruh keberadaan $\mathrm{P}$ dalam jumlah berlebih dalam medium pertumbuhan. Konsentrasi P sebesar 3 kali, 5 kali dan 10 kali $\mathrm{KH}_{2} \mathrm{PO}_{4}$ menunjukkan produktivitas biomassa Oocystis sp. yang cenderung konstan namun lebih baik daripada perlakuan tanpa $\mathrm{KH}_{2} \mathrm{PO}_{4}$. Hasil yang sama juga didapatkan oleh Moussa et al. (2017) pada mikroalga Tetraselmis marina yang tetap bertahan di bawah kondisi defisiensi P walaupun dari segi produktivitas biomassa menurun dari pada perlakuan kelebihan P. Produktivitas biomassa akibat perlakuan induksi dengan kelebihan $\mathrm{KH}_{2} \mathrm{PO}_{4}$ terdeteksi dengan baik, hal ini kemungkinan disebabkan peranan $\mathrm{K}$ dalam makronutrien tersebut. Unsur $\mathrm{K}$ merupakan kofaktor pada banyak reaksi enzim yang mempengaruhi laju pertumbuhan dan perkembangan (Talling, 2010).

Unsur $\mathrm{N}$ dan $\mathrm{P}$ merupakan makronutrien untuk pertumbuhan dan metabolisme dari sel alga. $\mathrm{N}$ adalah unsur fundamental untuk membentuk protein dan asam nukleat. $\mathrm{N}$ terintegrasi pada molekul esensial seperti ATP. P juga merupakan komponen yang sangat penting. $\mathrm{P}$ merupakan backbone dari DNA dan RNA yang merupakan makromolekul esensial untuk kehidupan semua sel. Selain itu, $P$ merupakan komponen kunci dari fosfolipid (Juneja, Ceballos, \& Murthy, 2013).

\section{Efek Induksi terhadap Pigmen Fotosintesis Oocystissp.}

Perlakuan induksi terhadap mikroalga Oocystis sp., berpengaruh terhadap kandungan pigmen fotosintesisnya (Gambar 4). Analisis statistik menunjukkan bahwa perlakuan stres $\mathrm{N}$ dan $\mathrm{P}$ memberikan pengaruh yang signifikan terhadap kandungan pigmen klorofil a, klorofil b serta karotenoid pada mikroalga Oocystis sp. $(\mathrm{p}<0,05)$. Kandungan karotenoid total dengan medium induksi tanpa $\mathrm{NaNO}_{3}$ terdeteksi lebih tinggi dibandingkan medium induksi yang memiliki kelebihan kandungan $\mathrm{NaNO}_{3}$ seperti $3 \times \mathrm{NaNO}_{3}, 5 \times \mathrm{NaNO}_{3}$, dan $10 \times \mathrm{NaNO}_{3}$. $\mathrm{Hal}$ tersebut menunjukkan faktor kekurangan $\mathrm{N}$ menstimulus respon fisiologis dengan cepat yang selanjutnya diarahkan kedalam jalur biosintesis metabolit sekunder termasuk karotenoid. Secara umum defisiensi $\mathrm{N}$ mempunyai efek yang lebih baik daripada kelebihan $\mathrm{N}$ terhadap kandungan karotenoid. Berdasarkan penelitian yang telah dilakukan oleh
Borowitzka et al. (1991) terjadi peningkatan karotenoid jenis astaxantin pada mikroalga Haematococcus pluvialis karena kondisi defisiensi N. Pada kondisi kultur mikroalga dengan kandungan $\mathrm{N}$ yang rendah, mikroalga akan menjadikan karbon $(\mathrm{C})$ yang terdapat pada sel dan medium untuk sintesis karotenoid, sedangkan kultur yang kaya dengan nitrogen menjadikan karbon sebagai bahan untuk asimilasi nitrogen.

Nilai klorofil a dan b terdeteksi lebih rendah di dalam medium pertumbuhan tanpa $\mathrm{N}$ dibandingkan dengan medium yang kelebihan $\mathrm{N}$, nilai-nilai tersebut berbanding terbalik dengan kandungan karotenoidnya. Klorofil akan mudah terdeteksi pada medium yang kaya $\mathrm{N}$, karena $\mathrm{N}$ tersebut digunakan sebagai $\mathrm{N}$ intraseluler untuk mendukung lebih lanjut pertumbuhan sel dan produksi biomassa sampai $\mathrm{N}$ di media tersebut berkurang ( $\mathrm{Li}$ et al., 2008). Sebagai contoh Chlamydomonas reinhartdtii dan Scenedesmus subpicatus hanya memasuki fasa stationer saat level $\mathrm{N}$ dalam medium di bawah 0,05 mg/L (Dean, Sigee, Estrada, \& Pittman, 2010).

Studi lain melaporkan, ketika $\mathrm{N}$ ditambahkan ke dalam medium inokulum Chorella minutissima yang telah kekurangan $\mathrm{N}$, ternyata terjadi peningkatan kandungan klorofil a dan b. Hal ini mengindikasikan keberadaan $\mathrm{N}$ dalam medium menyebabkan akumulasi pada klorofil a dan b. Pada perlakuan $\mathrm{N}$ yang lebih tinggi akan terjadi perbaikan dari klorofil, selanjutnya akan menunjukkan laju pertumbuhan lebih cepat. Akan tetapi pada medium yang kekurangan $\mathrm{N}$, maka klorofil akan didegradasi menjadi $\mathrm{N}$ dan digunakan kembali untuk pertumbuhan dengan kandungan klorofil a dan b yang lebih rendah. Hasil yang sama juga terjadi penurunan klorofil dengan cepat pada mikroalga Neochloris oleoabundus yang telah dikultur selama 2 hari ( $\mathrm{Li}$ et al., 2008).

Pada perlakuan induksi dengan $5 \times \mathrm{KH}_{2} \mathrm{PO}_{4}$ dan 10x $\mathrm{KH}_{2} \mathrm{PO}_{4}$ kandungan karotenoid terdeteksi lebih tinggi namun kandungan klorofil a dan $\mathrm{b}$ terdeteksi lebih rendah, sedangkan untuk perlakuan $3 \times \mathrm{KH}_{2} \mathrm{PO}_{4}$ dan tanpa $\mathrm{KH}_{2} \mathrm{PO}_{4}$ memiliki kandungan karotenoid yang rendah namun dengan kandungan klorofil a dan $\mathrm{b}$ yang lebih tinggi. Kekurangan $\mathrm{P}$ dalam medium mampu menurunkan produktivitas biomassa serta kandungan karotenoid namun tidak memberikan efek penurunan terhadap pigmen klorofil pada mikroalga (Kozlowska-Szerenos et al., 2000).

Unsur $\mathrm{P}$ mempunyai peranan dalam proses metabolisme energi. Kelebihan atau peningkatan kandungan $\mathrm{P}$ dalam medium pertumbuhan mikroalga Tetraselmis marina memberikan korelasi positif terhadap kandungan karotenoidnya (Moussa et al., 2017), selain itu peningkatan $P$ dan $N$ dalam medium pertumbuhan terdeteksi mampu meningkatkan pigmen 


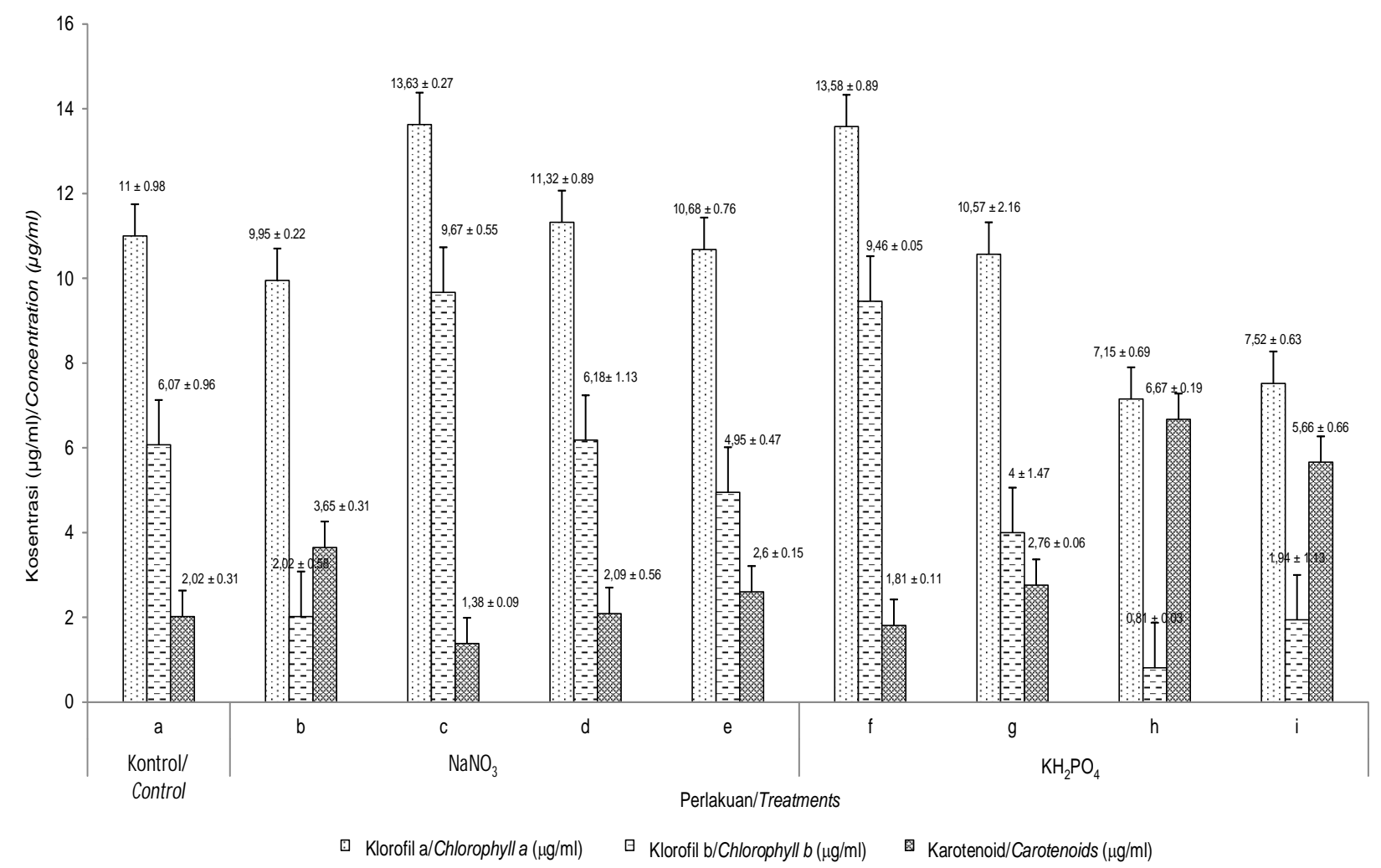

Keterangan/Notes :

$\mathrm{a}=$ BBM normal $0,3 \mathrm{M} \mathrm{NaNO}_{3}$ dan $0,1 \mathrm{M} \mathrm{KH}_{2} \mathrm{PO}_{4} /$ Normal BBM 0.3 $\mathrm{MNaNO}_{3} 0.1 \mathrm{M}$ and $\mathrm{KH}_{2} \mathrm{PO}_{4}$

$\mathrm{b}=$ BBM tanpa $\mathrm{NaNO}_{3} /$ without $\mathrm{NaNO}_{3}$

$\mathrm{f}=\mathrm{BBM}$ tanpa $\mathrm{KH}_{2} \mathrm{PO}_{4} / B B M$ without $\mathrm{KH}_{2} \mathrm{PO}_{4}$

$\mathrm{c}=\mathrm{BBM}$ dengan $3 \times \mathrm{NaNO}_{3} / B B M$ with $3 x \mathrm{NaNO}_{3}$

$\mathrm{d}=\mathrm{BBM}$ dengan $5 \times \mathrm{NaNO}_{3} / / \mathrm{BBM}$ with $5 \times \mathrm{NaNO}_{3}$

$\mathrm{e}=$ BBM dengan $10 \times \mathrm{NaNO}_{3} / \mathrm{BBM}$ with $10 \times \mathrm{NaNO}_{3}$

$\mathrm{g}=\mathrm{BBM}$ dengan $3 \times \mathrm{KH}_{2} \mathrm{PO}_{4} / \mathrm{BBM}$ with $3 \times \mathrm{KH}_{2} \mathrm{PO}_{4}$

$\mathrm{h}=\mathrm{BBM}$ dengan $5 \times \mathrm{KH}_{2} \mathrm{PO}_{4} / B B M$ with $5 \times \mathrm{KH}_{2} \mathrm{PO}_{4}$

$\mathrm{i}=$ BBM dengan $10 \times \mathrm{KH}_{2} \mathrm{PO}_{4} / B B M$ with $10 \times \mathrm{KH}_{2} \mathrm{PO}_{4}$

Gambar 4. Efek konsentrasi $\mathrm{NaNO}_{3}$ dan $\mathrm{KH}_{2} \mathrm{PO}_{4}$ terhadap kandungan pigmen fotosintesis

Figure 4. The effects concentrations of $\mathrm{NaNO}_{3}^{2}$ and $\mathrm{KH}_{2} \mathrm{PO}_{4}$ on the pigment content of photosynthesis

fotosintesis pada mikroalga Hypnea musciformis (Martins, Junior, Colepicolo, \& Yokoya, 2011).

Mikroalga diketahui memproduksi pigmen dan senyawa bioaktif yang terfokus pada tiga jenis antara lain klorofil, phicobillin dan karotenoid (Abalde, Fabregas, \& Herrero, 1991). Pigmen fotosintesis seperti klorofil a dan b memiliki peranan penting dalam proses fotosintesis. Hasil penelitian ini menunjukkan bahwa konsentrasi nutrien dapat mempengaruhi kandungan pigmen pada mikroalga Oocystis sp.

\section{Analisis $\beta$-karoten}

Analisis standar $\beta$-karoten dengan HPLC menghasilkan persamaan regresi $y=12.790 .618,26$ $x-50.841,04$ dengan nilai $R 2=0,94$. Kandungan $\beta$ karoten tertinggi pada mikroalga Oocystis sp. terdeteksi pada perlakuan induksi dengan kandungan medium BBM dengan $5 \times \mathrm{KH}_{2} \mathrm{PO}_{4}$ yaitu sekitar $0,22 \%$ dari berat kering biomassa mikroalga (Gambar 5).
Persentase demikian mengindikasikan bahwa kandungan $\beta$-karoten mikroalga Oocystis sp. terbilang cukup baik. Menurut Miledge, kosentrasi rata-rata karotenoid ( $\beta$-karoten) pada mikroalga secara umum adalah $0,1-2 \%$ (Milledge, 2011).

Pengaruh induksi medium BBM dengan kandungan $5 \mathrm{x} \mathrm{KH}_{2} \mathrm{KO}_{4}$ terhadap $\beta$-karoten pada mikroalga Oocystis sp. dapat dinyatakan lebih tinggi 1,6 kali lipat dibandingkan dengan mikroalga yang tidak diberi perlakuan induksi sama sekali. Selain itu produktivitas biomassanya pun hampir sama dengan mikroalga yang diinduksi dengan medium BBM normal yaitu $0,001 \mathrm{~g} / \mathrm{mL} /$ hari. Dengan demikian, perlakuan induksi dengan medium yang kaya fosfor memberikan efek yang positif terhadap sintesis $\beta$-karoten pada mikroalga Oocystis sp.

Kandungan $\beta$-karoten (Gambar 5) pada perlakuan induksi tanpa $\mathrm{KH}_{2} \mathrm{PO}_{4}$ tidak terdeteksi sama sekali. Hasil yang sama juga ditemukan pada mikroalga 
Nannochloropsis, bahwa tidak terjadi peningkatan kandungan karotenoid jenis $\beta$-karoten pada mikroalga yang ditumbukan dalam medium dengan kandungan $P$ yang kurang, namun terjadi peningkatan pada zeaxantin. Selain $\beta$-karoten, karotenoid lain yang tidak mengalami peningkatan adalah violaxantin dan cantaxantin (Forján, Garbayo, Casal, \& Vílchez, 2007).

Perlakuan induksi terhadap mikroalga Oocystis sp. dengan medium BBM tanpa $\mathrm{NaNO}_{3}$ terdeteksi memiliki kandungan $\beta$-karoten sekitar $0,19 \%$ berat kering mikroalga (Gambar 5). Data tersebut menunjukkan peningkatan kandungan $\beta$-karoten akibat proses induksi sekitar 1,34 kali lipat dibandingkan dengan mikroalga yang tidak diberikan perlakuan induksi. Secara umum defisiensi $\mathrm{N}$ mempunyai efek yang lebih baik dalam produksi $\beta$-karoten daripada kondisi kelebihan N, seperti pada mikroalga Dunaliella salina yang memberikan efek peningkatan kandungan $\beta$ karoten diatas 2,7\% berat kering mikroalga (Minhas, Hodgson, Barrow, \& Adholeya, 2016). Namun berbeda dengan hasil penelitian yang didapatkan oleh Couso et al. (2012) pada mikroalga Chlamydomonas reinhardtii, bahwa defisiensi nitrogen pada medium pertumbuhan tidak memberikan hasil yang lebih baik terhadap karotenoid jenis $\beta$-karoten namun menunjukkan hasil yang lebih baik pada jenis karotenoid lainnya seperti zeaxantin. Hal tersebut disebabkan oleh aktivasi siklus xantofil.

\section{KESIMPULAN}

Pada proses penapisan mikroalga penghasil karotenoid dari perairan Danau Atas diperoleh Oocystis $\mathrm{sp}$. sebagai spesies yang mampu bertahan terhadap stres oksidatif sinar UV-A $326 \mathrm{~nm}$. Karotenoid jenis $\beta$-karoten pada Oocystis sp. dapat dioptimalkan dengan cara pemberian stres nutrien $\mathrm{N}$ dan $\mathrm{P}$. Hasil menunjukkan induksiOocystis sp. dengan medium BBM yang mengandung $5 \times \mathrm{KH}_{2} \mathrm{PO}_{4}$ memberikan hasil yang lebih baik dibandingkan dengan perlakuan induksi lainnya. Penelitian selanjutnya diharapkan dapat melakukan analisis terhadap kandungan karotenoid jenis lainnya seperti astaxantin, zeaxantin, lutein dan masih banyak lagi.

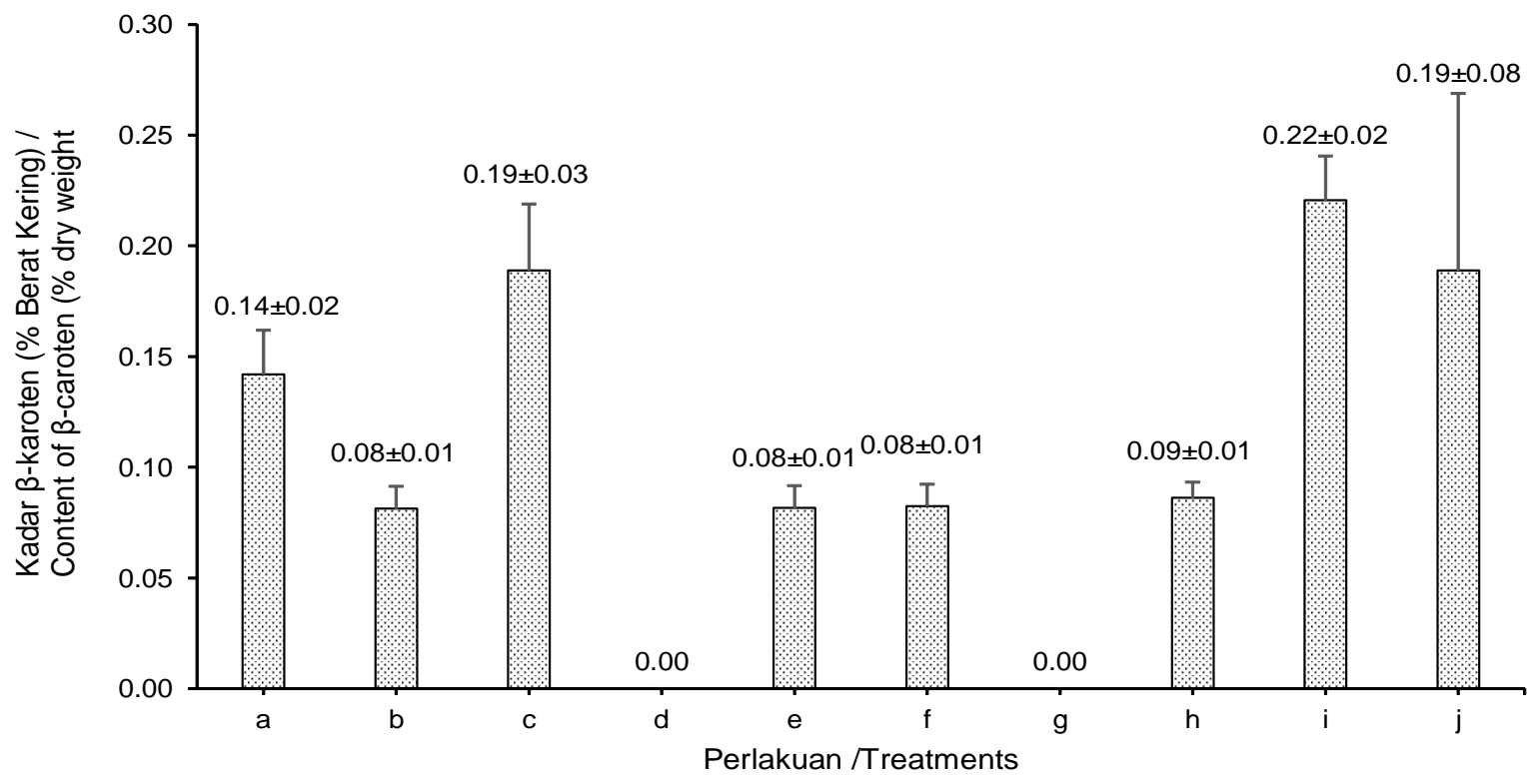

Keterangan/Notes :

$a=$ Tidak diinduksi/No induction

$\mathrm{b}=\mathrm{BBM}$ normal/Normal BBM

$\mathrm{C}=\mathrm{BBM}$ tanpa $\mathrm{NaNO}_{3} / \mathrm{BBM}$ without $0 \mathrm{NaNO}_{3}$

$\mathrm{d}=\mathrm{BBM}$ dengan $3 \times \mathrm{NaNO}_{3} / B B M$ with $3 \times \mathrm{NaNO}_{3}$

$\mathrm{e}=\mathrm{BBM}$ dengan $5 \times \mathrm{NaNO}_{3} / \mathrm{BBM}$ with $5 x \mathrm{NaNO}_{3}$

$\mathrm{f}=\mathrm{BBM}$ dengan $10 \times \mathrm{NaNO}_{3} / \mathrm{BBM}$ with $10 \times \mathrm{NaNO}_{3}$

$\mathrm{g}=\mathrm{BBM}$ tanpa $\mathrm{KH}_{2} \mathrm{PO}_{4} / \mathrm{BBM}$ without $0 \mathrm{KH}_{2} \mathrm{PO}_{4}$

$\mathrm{h}=\mathrm{BBM}$ dengan $3 \times \mathrm{KH}_{2} \mathrm{PO}_{4} / B B M$ with $3 \times \mathrm{KH}_{2} \mathrm{PO}_{4}$

$\mathrm{i}=\mathrm{BBM}$ dengan $5 \times \mathrm{KH}_{2} \mathrm{PO}_{4} / B B M$ with $5 \times \mathrm{KH}_{2} \mathrm{PO}_{4}$

$\mathrm{j}=\mathrm{BBM}$ dengan $10 \times \mathrm{KH}_{2} \mathrm{PO}_{4} / B B M$ with $10 \times \mathrm{KH}_{2} \mathrm{PO}_{4}$

Gambar 5. Kadar $\beta$-karoten pada mikroalga Oocystis sp dalam beberapa perlakuan

Figure 5. The levels of $\beta$-carotene in Oocystis sp microalgae in several treatments 


\section{UCAPAN TERIMA KASIH}

Peneliti mengucapkan terima kasih kepada pihakpihak yang telah membantu penyelesaian penelitian dan penyusunan artikel ilmiah ini. Terucap kepada analis Laboratorium Biokimia, Genetika, FMIPA Universitas Andalas, dan Analis Laboratorium Dasar Sentral Universitas Andalas.

\section{DAFTAR PUSTAKA}

Abalde, J., Fabregas, J., \& Herrero, C. (1991). âCarotene, vitamin $C$ and vitamin $E$ content of the marine microalga Dunaliella tertiolecta cultured with different nitrogen sources. Bioresource Technology, 38(2-3), 121-125. https://doi.org/10.1016/09608524(91)90142-7

Asker, D., \& Ohta, Y. (1999). Production of canthaxanthin by extremely halophilic bacteria. Journal of Bioscience and Bioengineering, 88(6), 617-621. https://doi.org/ 10.1016/S1389-1723(00)87089-9

Borowitzka, M. A., Huisman, J. M., \& Osborn, A. (1991). Culture of the astaxanthin-producing green algaHaematococcus pluvialis 1 . Effects of nutrients on growth and cell type. Journal of Applied Phycology, 3(4), 295-304. https://doi.org/10.1007/BF02392882

Coates, C. R., Trentacoste, E., \& Gerwick, W. H. (2013). Bioactive and novel chemicals from microalgae. In A. Richmond \& Q. Hu (Eds.), Handbook of microalgal culture (pp. 504-531). John Wiley \& Sons, Ltd. https:/ /doi.org/10.1002/9781118567166.ch26

Couso, I., Vila, M., Vigara, J., Cordero, B. F., Vargas, M. Á., Rodríguez, H., \& León, R. (2012). Synthesis of carotenoids and regulation of the carotenoid biosynthesis pathway in response to high light stress in the unicellular microalga Chlamydomonas reinhardtii. European Journal of Phycology, 47(3), $223-232$. ht t p s://do i . org/10.1080/ 09670262.2012 .692816

Dean, A. P., Sigee, D. C., Estrada, B., \& Pittman, J. K. (2010). Using FTIR spectroscopy for rapid determination of lipid accumulation in response to nitrogen limitation in freshwater microalgae. Bioresource Technology, 101(12), 4499-4507. https:/ /doi.org/10.1016/j.biortech.2010.01.065

Forján, E., Garbayo, I., Casal, C., \& Vílchez, C. (2007). Enhancement of carotenoid production in. In A. Méndez-Vilas (Ed.), Communicating Current Research and Educational Topics and Trends in Applied Microbiology (pp. 356-364). Formatex.

Hernandi, R.; Dharma, A. A. (2018). Screening, Isolation, and Characterization of the Potential Microalgae as Biodiesel Production from Lake Kerinci, Jambi, 9(6), 5.

Juneja, A., Ceballos, R. M., \& Murthy, G. S. (2013). Effects of environmental factors and nutrient availability on the biochemical composition of algae for biofuels production: A review. Energies, 6(9), 4607-4638. https://doi.org/10.3390/en6094607

Kozlowska-Szerenos, B., Zieliñski, P., Stanis ${ }^{3} a w, \&$ Maleszewski. (2000). Involvement of glycolate metabolism in acclimation of Chlorella vulgaris cultures to low phosphate supply. Plant Physiology and Biochemistry, 38(9), 727-734. https://doi.org/ 10.1016/S0981-9428(00)01175-X

Lam, M. K., Yusoff, M. I., Uemura, Y., Lim, J. W., Khoo, C. G., Lee, K. T., \& Ong, H. C. (2017). Cultivation of Chlorella vulgaris using nutrients source from domestic wastewater for biodiesel production: Growth condition and kinetic studies. Renewable Energy, 103, 197-207. https://doi.org/10.1016/ j.renene.2016.11.032

Li, Y., Horsman, M., Wang, B., Wu, N., \& Lan, C. Q. (2008). Effects of nitrogen sources on cell growth and lipid accumulation of green alga Neochloris oleoabundans. Applied Microbiology and Biotechnology, 81(4), 629-636. https://doi.org/ 10.1007/s00253-008-1681-1

Lichtenthaler, H. K. (1987). Chlorophylls and Carotenoids: Pigments of Photosynthetic Biomembranes. Methods in Enzymology, 148(C), 350-382.https://doi.org/10.1016/00766879(87)48036-1

Martins, A. P., Junior, O. N., Colepicolo, P., \& Yokoya, N. S. (2011). Effects of nitrate and phosphate availabilities on growth, photosynthesis and pigment and protein contents in colour strains of Hypnea musciformis (Wulfen in Jacqu.) J.V. Lamour. (Gigartinales, Rhodophyta). Brazilian Journal of Pharmacognosy, 21(2), 340-348. https://doi.org/10.1590/S0102695X2011005000078

Milledge, J. J. (2011). Commercial application of microalgae other than as biofuels: A brief review. Reviews in Environmental Science and Biotechnology, 10(1), 31-41. https://doi.org/10.1007/ s11157-010-9214-7

Minhas, A. K., Hodgson, P., Barrow, C. J., \& Adholeya, A. (2016). A review on the assessment of stress conditions for simultaneous production of microalgal lipids and carotenoids. Frontiers in Microbiology, 7(MAY), 1-19. https://doi.org/10.3389/fmicb.2016.00546

Moussa, I. D.-B., Chtourou, H., Karray, F., Sayadi, S., \& Dhouib, A. (2017). Nitrogen or phosphorus repletion strategies for enhancing lipid or carotenoid production from Tetraselmis marina. Bioresource Technology, 238, 325-332. https://doi.org/10.1016/ j.biortech.2017.04.008

Paliwal, C., Mitra, M., Bhayani, K., Bharadwaj, S. V. V., Ghosh, T., Dubey, S., \& Mishra, S. (2017). Abiotic stresses as tools for metabolites in microalgae. Bioresource Technology, 244, 1216-1226. https:// doi.org/10.1016/j.biortech.2017.05.058

Ramos, A., Coesel, S., Marques, A., Rodrigues, M., Baumgartner, A., Noronha, J., ... Varela, J. (2008). Isolation and characterization of a stress-inducible Dunaliella salina Lcy-beta gene encoding a functional lycopene beta-cyclase. Applied Microbiology and Biotechnology, 79(5), 819. https://doi.org/10.1007/ s00253-008-1492-4

Sekatresna, W., Dharma, A., Zein, R., \& Chaidir, Z. (2016). Identification of blue-green algae uncultured oscillatoria sp IPOME-4 isolated from local industry 
effluent with the potential as $\beta$-carotene feedstock. Der Pharma Chemica, 8(12), 110-117.

Singh, P., Gupta, S. K., Guldhe, A., Rawat, I., \& Bux, F. (2015). Microalgae isolation and basic culturing techniques. In S.-K. Kim (Ed.), Handbook of marine microalgae (pp. 43-54). Boston: Academic Press. https://doi.org/ 10.1016/B978-0-12-800776-1.00004-2

Stafsnes, M. H., Josefsen, K. D., Kildahl-Andersen, G., Valla S., Ellingsen, T. E., \& Bruheim, P. (2010). Isolation and characterization of marine pigmented bacteria from
Norwegian coastal waters and screening for carotenoids with UVA-blue light absorbing properties. Journal of Microbiology, 48(1), 16-23. https://doi.org/ 10.1007/s12275-009-0118-6

Talling, J. F. (2010). Potassium- A non-limiting nutrient in fresh waters?.Freshwater Reviews, 3(2), 97-104. Retrieved from https://doi.org/10.1608/FRJ-3.2.1

Wehr, J. D. (2018). Algae/ : Anatomy, Biochemistry, and Biotechnology by Barsanti , L . \& Gualtieri ,. https:// doi.org/10.1111/j.1529-8817.2007.00335.x 
JPB Kelautan dan Perikanan Vol. 14 No. 1 Tahun 2019: 9-20 